Jahangirnagar University J. Biol. Sci. 8(1): 45-55, 2019 (June)

\title{
Establishment of a functional and sustainable bio-system engineering process for the saccharification of starch with industrial focus
}

\author{
Shatabdy Saha, Md. Zahidul Islam*, Umme Salma Zohora, Mohammed Salahuddin, \\ Sabbir Janee and Mohammad Shahedur Rahman \\ Department of Biotechnology and Genetic Engineering, Jahangirnagar University, \\ Savar, Dhaka-1342, Bangladesh
}

\begin{abstract}
Enzyme immobilization provides an excellent opportunity to use the enzymes for several times with greater productivity. The main aim of the present study is the establishment of a functional and sustainable bio-system engineering process based on immobilized $\alpha$-amylase enzyme for the saccharification of starch with industrial focus as well as cost effective sustainable bioprocess system by using indigenous industrial waste materials as carrier agents. In this study, $\alpha$-amylase was immobilized in different types of support matrices like alginate, sawdust, sugarcane bagasse and the activity of immobilized enzymes were analyzed for the breakdown of starch. The experimental results showed that the productivity of immobilized enzyme was around 2.3 times higher than the free enzyme. Conjugates of bagasse-alginate showed the highest result. A fixed batch immobilized enzyme bioreactor had been developed which could be used for the production of various valuable products in the industrial scale.
\end{abstract}

Key words: Immobilization, $\alpha$-amyalse, alginate, sawdust, sugarcane bagasse

\section{INTRODUCTION}

Enzyme is a biocatalyst which regulates the rate of proceeding chemical reactions and it is unaltered in the process. One of the most important roles of enzymes as natural biocatalysts is their ability to increase the rate of virtually of all chemical reactions within a cell (Cooper, 2000; Robinson, 2015; Cheetham, 1987). The reactions takes a long time to be completed without the presence of catalysts. However, the reaction being completed within the fractions of a second in the presence of a proper enzyme (Hernandez \& Fernandez-Lafuente, 2011). There are a large number of enzymes, which are now being used in various industries where extremely specific catalysis is required. Some of the enzymes are cellulase, amylase, lipase, protease, papain, lignicellulase, hemicellulase, pectinase and nuclease etc.

Enzyme $\alpha$-amylase split the $\alpha$-D-(1-4) glycosidic bonds of starch (Tangphatsornruang et al., 2005). The end products of $\alpha$-amylase action is oligosaccharides with both $\alpha-1,4$ and $\alpha-1,6$ linkages (Whitcomb \& Lowe, 2007). Amylases have a very wide application in food, fermentation and pharmaceutical industries (Tangphatsornruang et al., 2005). The $\alpha$-amylase is produced in microorganisms, plants and higher organisms (Reshmi et al., 2007). The $\alpha$-amylase which is produced by Aspergillus species are extracellular enzyme.

\footnotetext{
* Corresponding author. E-mail: zahidul.islam@bgeju.edu.bd
} 
These are considered the best for the industrial uses (Hernández et al., 2006). Bacterial and fungal $\alpha$-amylases enzyme is most popular and important form for the industrial applications (Gupta et al., 2003; Kandra, 2003).

The most of the enzymes are unstable in ambient condition. As a result, industrial application is often hampered by a lack of long-term operational stability and the technically challenging recovery process and reuses the enzyme for the further chemical reaction (Sheldon, 2007). In order to make enzyme utilization more favorable in biotechnological processes, different methods of cost reduction have been put into practice and immobilization is one of them. Immobilization is defined as imprisonment of the enzyme in a support or matrix (Kawaguti et al., 2006). Enzyme immobilization is the simplest technique which has several benefits. These are: products can be easily separated from enzyme; downstream product processing is very easy, making the process cost effective, reliable and efficient. This method facilitates easier handling and product separation along with reusability, higher stability in extreme conditions and easier process control with various interior designs (Hernandez and Fernandez-Lafuente, 2011; Asuri et al., 2006; Saifuddin et al., 2012). There are a lot of materials being used as support materials for enzyme immobilization. Cellulose is a common support material (Czaja et al., 2007). Cellulose is very cheap and there are a number of hydroxyl group on its surface. The characteristics of cellulose such as biocompatibility, biodegradability, chemical stabilization and low contamination risk to the environment have made it a matter of interest for enzyme immobilization (Klemm, et al., 2005). There are different methods for treatment of cellulose to make it compatible for the enzyme immobilization like esterification, periodate oxidation, 2, 2, 6, 6-tetramethylpyperidin-1-oxyl (TEMPO) mediated oxidation etc (Liu \& Chen, 2016).

In Bangladesh, the application of the immobilized enzymes in industrial scale is rare. However, it will be very much economical, if it is possible to establish a bio-system engineering process based on immobilized enzyme using local resources such as sawdust, rice bran and bagasse as support materials for the desired product. In this study, $\alpha$ amylase was immobilized in alginate beads and cellulosic material like sawdust and bagasse to produce the oligosaccharides from the starch. Several fixed bed reactor was developed to produce the oligosaccharides by using different support matrices for the immobilization of $\alpha$-amylase enzyme. The present study will help to understand about how the enzyme was immobilized, what are the parameters have to be optimized, comparison of immobilized enzyme with free enzyme and what are the benefits of using these matrices.

\section{MATERIALS AND METHODS}

Required reagents: Enzyme $\alpha$-amylase and 3,5-dinitrosalicylic acid were purchased from Signa-Aldrich, Switzerland. Starch, phenol, sodium sulfite, sulphuric acid, sodium alginate and sodium metaperiodate were purchased from Merck, India. Other reagents like sodium hydroxide, sodium potassium tatrate (rochelle salt) and calcium chloride were purchased from Merck, Germany. The cellulosic materials such as sawdust, baggase and 
rice bran were collected from sawmill, cane juice seller and rice mill, respectively from Savar, Dhaka, Bangladesh.

Treatment of cellulosic materials: Cellulosic materials, if required, were cut into small pieces and then boiled three times in 1.25\% sulphuric acid and purified with $1.25 \%$ sodium hydroxide. Then the materials were washed with distilled water up to 1 hour (Varavinit et al., 2001).

Oxidation of cellulosic materials: The treated samples $(5 \mathrm{~g})$ of each were taken into two different conical flasks. These samples were soaked in $375 \mathrm{~mL}$ of $0.03 \mathrm{M}$ periodic acid (sodium metaperiodate and sulphuric acid, $\mathrm{pH}$ 3.0). Then these flasks were incubated overnight in a shaking water bath at $60{ }^{\circ} \mathrm{C}$ with constant shaking at $120 \mathrm{rpm}$. The samples were then filtered and washed three times with distilled water before drying (Varavinit et al., 2001).

Preparation of alginate beads: Sodium alginate (4\%) was dissolved in distilled water. Then beads of alginate had been formed by dripping the alginate solution in $0.2 \mathrm{M} \mathrm{CaCl}_{2}$ using a syringe. Then the beads were kept for 30 minutes in the $\mathrm{CaCl}_{2}$ solution without any disturbances. The beads were separated by using filter paper and washed two times with distilled water. The beads were soaked in distilled water in a falcon tube and kept it at $4{ }^{\circ} \mathrm{C}$ for further use.

Determination of reducing sugar produced by support matrices without enzyme: Two $\mathrm{g}$ of each material (sawdust, bagasse and alginate beads) was taken in different falcon tubes and $25 \mathrm{~mL}$ of starch solution $(1 \%)$ was added in each tube. For control experiment, $25 \mathrm{~mL}$ of starch solution (1\%) and free enzyme were taken in a falcon tube. All the tubes were incubated for 30 minutes at $37^{\circ} \mathrm{C}$. Then $2 \mathrm{~mL}$ solution from each tube was taken into new test tubes and $2 \mathrm{~mL}$ of freshly prepared DNS reagent (3,5dinitrosalicylic acid, crystal of phenol, sodium sulfite and sodium hydroxide in distilled water) was added and incubated all the test tubes at $90^{\circ} \mathrm{C}$ for 10 minutes in a water bath. Then $1 \mathrm{ml}$ of $40 \%$ Rochelle salt was added to each tube immediately after incubation. The solutions temperature was reduced to room temperature and optical density (OD) of control and samples solutions were measured at $575 \mathrm{~nm}$ wavelength.

Preparation of enzyme solution: Enzyme $\alpha$-amylase was purchased in powder form. The potency of the enzyme was $30 \mathrm{U} / \mathrm{mg}$. Fifty $\mathrm{mL}$ solution of $\alpha$-amylase was prepared by dissolving $50 \mathrm{mg}$ of enzyme (powder) in $50 \mathrm{~mL}$ of $16 \mathrm{mM}$ sodium acetate buffer solution.

Immobilization of $\boldsymbol{\alpha}$-amylase in various matrices: Dried samples ( $2 \mathrm{~g}$ each) were immersed in $12.5 \mathrm{~mL}$ of $\alpha$-amylase (30 U/mL) solution and incubated in a shaking water bath at $37^{\circ} \mathrm{C}$ for 30 minutes. Then the samples were filtered with filter paper to remove excess enzyme and washed five times with distilled water. Free enzyme was removed from the immobilized matrix during the washing steps. The total enzyme content in the immobilized matrix was maintained similar to the free enzyme in positive control. Then the samples were taken into clean falcon tubes. In case of enzyme immobilization in sodium alginate, the beads were prepared as described earlier. However, the difference is 
here, sodium alginate was first dissolved in water and then the enzyme solution was added and stirred gently for 30 minutes. After the formation of beads, they were harvested into a falcon tube.

Assay of free enzyme and immobilized enzyme in various support materials: Twenty five $\mathrm{mL}$ of $1 \%$ starch solution was added in each falcon tube containing different cellulosic materials and alginate beads. For positive control, $10 \mathrm{~mL}$ of $\alpha$-amylase enzyme solution (total enzyme $300 \mathrm{U}$ ) was added into another falcon tube containing $25 \mathrm{~mL}$ of $1 \%$ starch and for negative control, $5 \mathrm{~mL}$ of distilled water is added into a falcon tube containing $25 \mathrm{~mL}$ of $1 \%$ starch solution. All tubes were then incubated at $37{ }^{\circ} \mathrm{C}$ for 30 minutes. Then $2 \mathrm{~mL}$ from each tube was taken into new test tubes followed by DNS treatment and optical densities of each one were measured at $575 \mathrm{~nm}$ wavelength.

Preparation of fixed bed bioreactor with immobilized $\alpha$-amylase enzyme: A fixed bed bioreactor for the breakdown of starch was prepared using immobilized $\alpha$-amylase enzyme. This bioreactor had been used for the investigation of starch breakdown process using immobilized enzymes (Figure 1). In this bioreactor, there was a substrate reservoir which contains starch solution, a flow controller that can control the flow of starch entering into the reactor, the blue part is the support matrix with immobilized enzyme, the filter foam sheet provides mechanical support to the fixed bed and at the bottom there is a container for receiving the product.

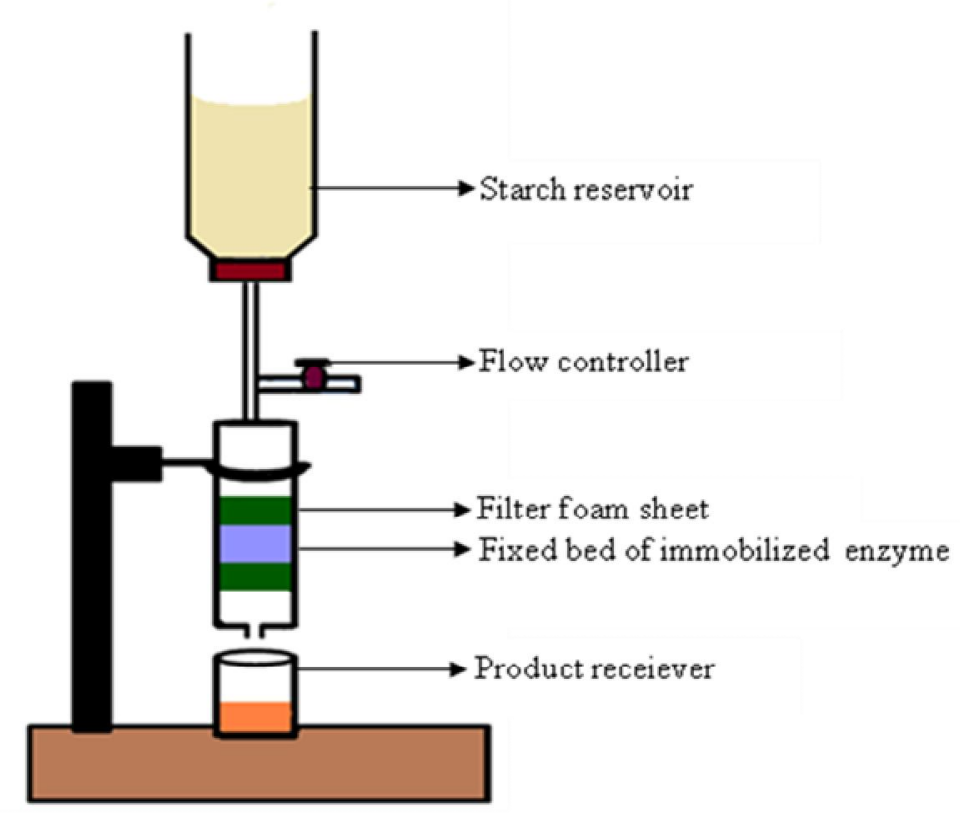

Fig. 1. Schematic diagram of fixed bed bioreactor with immobilized $\alpha$-amylase enzyme 
Establishment of different types of fixed bed reactor system: Five syringes $(50 \mathrm{~mL})$ were taken in order to prepare five different types of fixed bed reactor system. First fixed bed reactor system was prepared by dissolving $2 \mathrm{~g}$ of alginate in $12.5 \mathrm{~mL}$ of distilled water and mixed with $12.5 \mathrm{~mL}$ of $\alpha$-amylase solution $(30 \mathrm{U} / \mathrm{mL}$ ). Then $25 \mathrm{~mL}$ of $0.2 \mathrm{M}$ $\mathrm{CaCl}_{2}$ was added to the solution to make an enzyme alginate lump. After 30 minutes, the lump was taken in a syringe and washed two times with distilled water. Second fixed bed reactor system was prepared by dissolving $2 \mathrm{~g}$ of oxidized sawdust in $12.5 \mathrm{~mL}$ of distilled water and mixed with $12.5 \mathrm{~mL}$ of $\alpha$-amylase solution $(30 \mathrm{U} / \mathrm{mL})$ to make an enzyme sawdust lump. After 30 minutes, the lump was taken in a syringe and washed two times with distilled water. Third fixed bed reactor system was prepared by taking $2 \mathrm{~g}$ of oxidized bagasse in $12.5 \mathrm{~mL}$ of distilled water and mixed with $12.5 \mathrm{~mL}$ of $\alpha$-amylase solution $(30 \mathrm{U} / \mathrm{mL})$ to make an enzyme bagasse lump. After 30 minutes, the lump was taken in a syringe and washed two times with distilled water. Fourth fixed bed reactor system was prepared by dissolving $1 \mathrm{~g}$ of sodium alginate in $12.5 \mathrm{~mL}$ of distilled water. All components such as $1 \mathrm{~g}$ of oxidized sawdust, $12.5 \mathrm{~mL}$ of sodium alginate in solution and $12.5 \mathrm{~mL}$ of $\alpha$-amylase solution $\left(30 \mathrm{U} / \mathrm{mL}\right.$ ) were mixed. Then $25 \mathrm{~mL}$ of $0.2 \mathrm{M} \mathrm{CaCl}_{2}$ was added to the solution to make an enzyme alginate and sawdust lump. After 30 minutes, the lump was taken in a syringe and washed two times with distilled water. Fifth fixed bed reactor system was prepared by dissolving $1 \mathrm{~g}$ of sodium alginate in $12.5 \mathrm{~mL}$ of distilled water. All components such as $1 \mathrm{~g}$ of oxidized bagasse, $12.5 \mathrm{~mL}$ of sodium alginate in solution and $12.5 \mathrm{~mL}$ of $\alpha$-amylase solution $(30 \mathrm{U} / \mathrm{mL})$ were mixed. Then 25 $\mathrm{mL}$ of $0.2 \mathrm{M} \mathrm{CaCl}_{2}$ was added to the solution to make an enzyme alginate and bagasse lump. After 30 minutes, the lump was taken in a syringe and washed two times with distilled water.

In each case of fixed bed reactor system, the free enzyme was removed from the immobilized matrix during the washing steps. We maintained the total enzyme content in the immobilized matrix as same as the free enzyme in positive control.

Determination of activity of different conjugates without enzyme: Twenty five $\mathrm{mL}$ starch solution $(1 \%)$ was passed $(5 \mathrm{~mL} / \mathrm{min})$ through the conjugates of sawdust with alginate, bagasse with alginate and only alginate bead fixed bed reactor without enzyme. Then solutions from each fixed bed reactor were collected into different test tubes followed by DNS treatment and OD of various solutions was measured at $575 \mathrm{~nm}$ wavelength.

Determination of activity of different fixed bed reactor systems: Twenty five $\mathrm{mL}$ starch solution $(1 \%)$ was passed $(5 \mathrm{~mL} / \mathrm{min})$ through different types of reactors which were prepared with alginate and conjugated matrix with enzyme. Then solutions from each fixed bed reactor were collected into different test tubes. The reducing sugars present in various test tubes were measured by the DNS method at $575 \mathrm{~nm}$ wavelength using UV-Vis spectrophotometer. Positive control was free enzyme instead of immobilized enzyme. 
Reusability test of immobilized enzyme: The process of starch conversion was carried out for all reactor systems up to three cycles. In each cycle, the solutions from each fixed bed reactor were collected into different test tubes. The reducing sugars present in various test tubes were measured by the DNS method at $575 \mathrm{~nm}$ wavelength using UVVis spectrophotometer. In every cycle new solution of free enzyme was used as a positive control.

\section{RESULTS AND DISCUSSION}

Different types of cellulosic materials: Different types of cellulosic materials (sawdust and bagasse) were treated with sulphuric acid and purified with $1.25 \%$ sodium hydroxide. Then the materials were oxidized for the entrapment of the $\alpha$-amylase enzyme. We also prepared alginate $(4 \%)$ bead with enzyme or without enzyme. Figure 2 shows that the image of different types of support matrices which were used for the immobilization of $\alpha$ amylase enzyme.

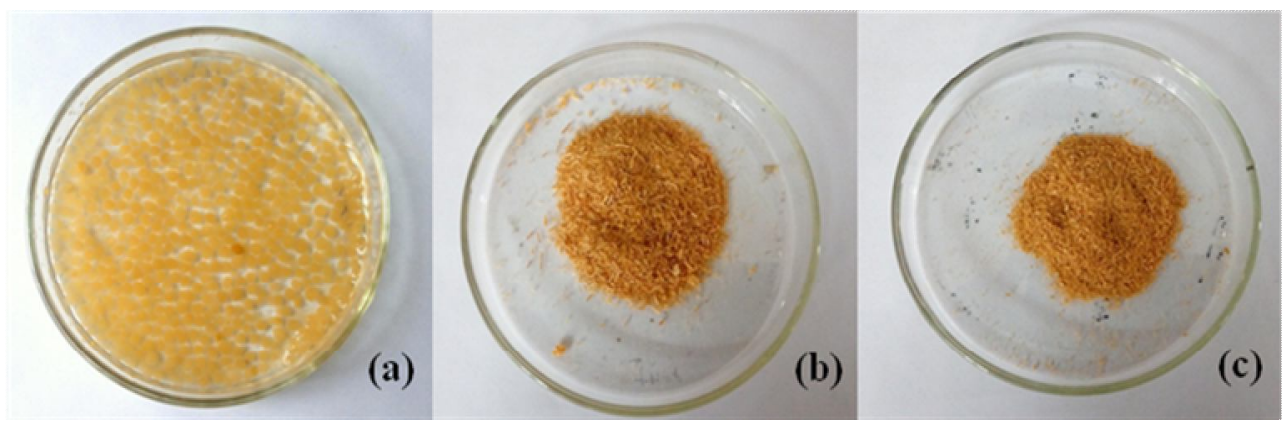

Fig. 2. Different types of support matrices which were being used for the immobilization of enzyme. (a) Alginate beads (b) Bagasse, and (c) Sawdust

Amount of reducing sugar produced by different support matrices without enzyme: To investigate whether the support materials have their native enzyme to breakdown the starch or not, this experiment was carried out for quantitative analysis of reducing sugar using DNS reagent treatment. Here, positive control was the free enzyme (total enzyme $300 \mathrm{U})$. The results showed that there was no enzyme present in different support materials (Figure 3). If the cellulosic materials show any enzymatic activity, they could not be used as a support material for the immobilization of enzyme. 


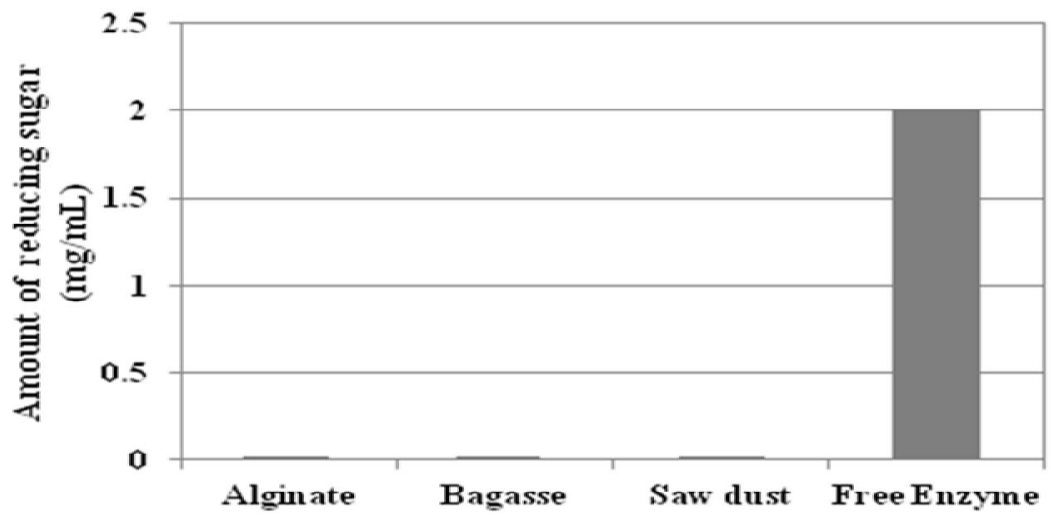

Fig. 3. Determination of native enzymatic activity of different types of support matrices in comparison to free $\alpha$-amylase enzyme

Activity of immobilized enzyme in various support materials: After immobilization of enzyme in the support materials, we want to know whether the immobilized enzyme was able to breakdown the starch or not. It was observed that the immobilized enzyme had the capacity to breakdown the starch though it was lower than the free enzyme (Figure 4). The graph shows that the immobilized enzyme in different support matrices had the ability to produce reducing sugar from starch molecules. The total amount of immobilized enzyme (total enzyme $300 \mathrm{U}$ ) in the matrix was similar to the total free enzyme (total enzyme $300 \mathrm{U}$ ) in positive control. Free enzyme had the highest activity, whereas bagasse had the lowest activity. Among the different support materials, the enzyme which was immobilized in alginate had the highest activity.

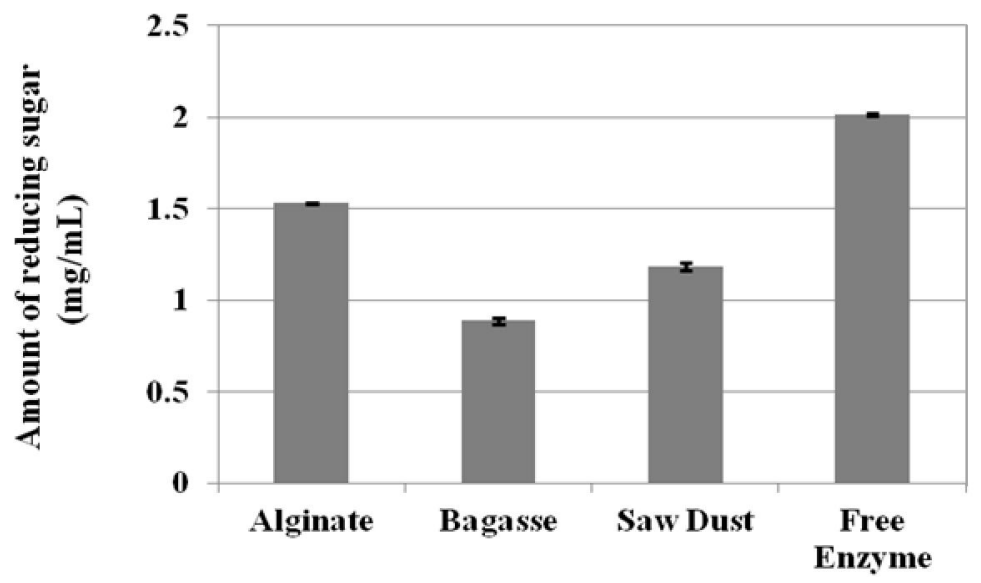

Fig. 4. Activity of immobilized enzyme in different support matrices in comparison with free $\alpha$-amylase enzyme

Activity of various fixed bed support materials without enzyme: The investigation was carried out using various types of fixed bed without enzyme such as alginate bead, 
alginate-saw dust bead, and alginate-bagasse bead. The positive control was free the enzyme solution (total enzyme $300 \mathrm{U}$ ). The result indicates that there was no enzymatic activity of various types of fixed bed support materials (Figure 5). It was confirmed that the conjugates did not have their own enzyme for the starch breakdown.

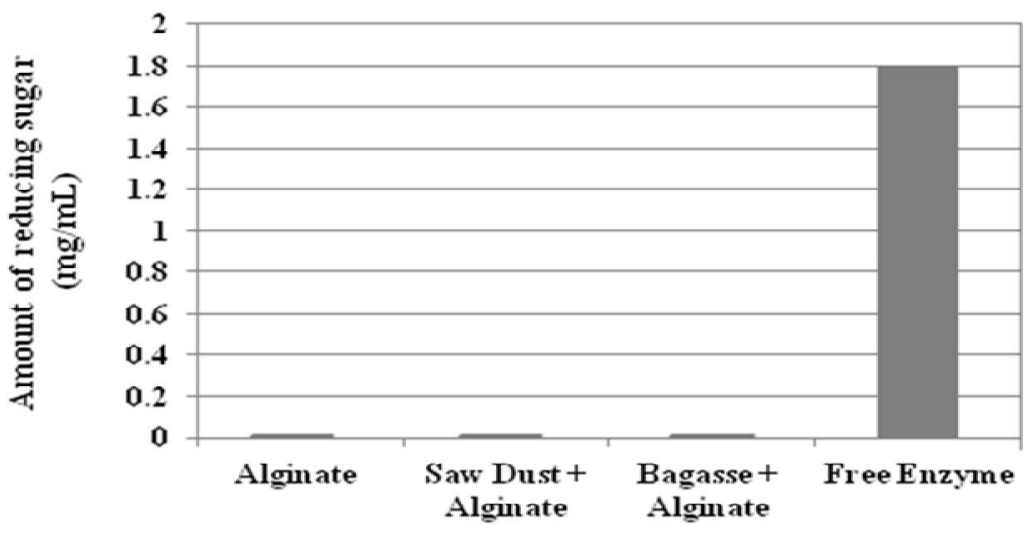

Fig. 5. Determination of native enzymatic activity of different types of conjugated matrices in comparison to free $\alpha$-amylase enzyme

Activity of immobilized enzyme in different fixed bed reactor systems: Three types of support matrices were used for immobilizing the enzyme and to develop a fixed bed reactor system for breaking down the starch. Figure 6 shows the activity of immobilized enzyme in different reactor systems. Among the conjugates, the highest activity was in bagasse-alginate conjugate and the lowest was in only alginate. The sawdust-alginate conjugate also showed the similar result as bagasse-alginate conjugate.

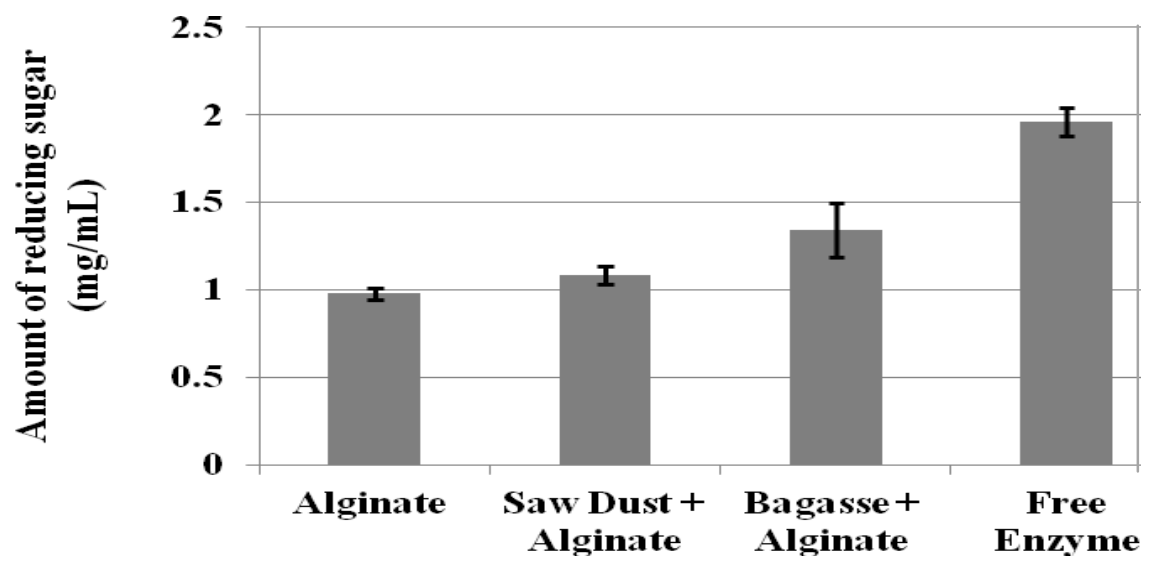

Fig. 6. Determination of activity of immobilized enzyme in different reactor systems in comparison to free enzyme 
Reusability of immobilized enzyme in different reactor system: To test the reusability of different types of reactor systems, the same immobilized enzyme reactor was used multiple times for the enzymatic degradation of starch molecule. The experimental results demonstrate that the immobilized enzyme could perform in multiple cycles and in every cycle have similar activity (Table 1). The enzyme immobilized in only bagasse showed the lowest activity, however the conjugates of bagasse and alginate had the maximum reusability. The results confirmed that the immobilized enzyme was more productive than free enzyme. The table also showed the comparison among different types of reactor system in terms of reusability.

Table 1. Enzyme reusability of different types of fixed bed reactor system

\begin{tabular}{l|cccc}
\hline \multirow{2}{*}{ Sample } & \multicolumn{3}{c}{ Amount of reducing sugar (mg/mL) } \\
\cline { 2 - 5 } & First cycle & Second Cycle & Third Cycle & Total \\
\hline Alginate & 1.5305 & 1.280 & 1.266 & 4.0765 \\
Sawdust & 1.150 & 0.885 & 0.6796 & 2.7146 \\
Bagasse & 0.8895 & 0.677 & 0.601 & 2.1675 \\
Sawdust and Alginate conjugates & 1.087 & 1.078 & 1.081 & 3.246 \\
Bagasse and alginate conjugates & 1.344 & 1.383 & 1.387 & 4.114 \\
\multicolumn{1}{c}{ Free enzyme } & 1.700 & --- & -- & 1.700 \\
\hline
\end{tabular}

The sulphuric acid treated samples (cellulosic materials) were oxidized with periodic acid. This oxidation process added the aldehyde group to the cellulosic materials. The longer the oxidation time, the increased number of aldehyde added to the materials. However, extreme oxidation can destruct the cellulosic materials into the fine cellulose powder which is not preferable for the immobilization of enzyme (Varavinit et al., 2001). Previous experimental result shows that various reagents such as calcium hypochlorite and other oxidants can be used for the oxidation of cellulosic matrix (Mehltretter, 1966). However, we oxidized the cellulosic materials with $0.03 \mathrm{M}$ periodic acid up to 12 hours and it acts as a good binder in the enzyme immobilization process.

Different concentration of sodium alginate were used and found that the $4 \%$ alginate concentration was optimized. Figure 3 and Figure 5 shows that the active enzyme was not attached with the support materials and thereby had no enzymatic activity. Figure- 4 results indicate that the rate of reaction of immobilized enzyme was moderate. The activity of immobilized enzyme was almost similar to the free enzyme. It indicates that there was no loss of enzyme during the immobilization process. However, to improve the condition, in the next experiment we used the conjugates for immobilization of the enzyme instead of use single support material. Two types of conjugates were used-one was comprised of sawdust and alginate and another one was comprised of bagasse and alginate. In case of bagasse-alginate conjugate, the activity of immobilized enzyme was the sensible. In case of positive control, the activity of free enzyme was the highest (Figure 6). However, the free enzyme can be used singularly. On the other hand, the immobilized enzyme could be used several times as indicated in table-1. It is noteworthy to mention that the reusability of the matrix was lowest when only bagasse was used but 
the rate of reusability was the improved when it was mixed with alginate. The potentially of the immobilized enzyme is remain similar after storing it in suitable condition for several days. According to Antony et al., the activity of $\alpha$-amylase immobilized enzyme retained up to $70 \%$ after 30 days storage, while the free enzyme lost its activity within 7days (Antony et al., 2016). In the present study, the immobilized enzyme was used up to three cycles and the amount of product was almost three times higher than the free enzyme. The cycle could be further increased as the fixed bed is still in the same working condition after conducting three cycles. The bioreactor we made here can be used for various types of enzymatic reactions in future.

In the field of biotechnology, immobilized enzymes have a great potential. In spite of lower activity in some cases, the immobilized enzymes have some extraordinary characteristics over free enzymes. The best advantages of the immobilized enzyme system are: (i) easy separation of substrates and products from the reaction medium (ii) easy separation of the enzyme (iii) repeated use and (iv) reduction of time and cost. Therefore, the immobilized enzymes have a greater potential impact in industrial level. In the present research, $\alpha$-amylase immobilized in alginate showed great activity. However, one of the greatest disadvantages of alginate is its cost. Another problem, it is not available in our local market. Sawdust and bagasse are mainly waste materials which were being recycled. These materials are very inexpensive and can be obtained from local market. Therefore, the bioreactor system of immobilized $\alpha$-amylase using conjugate of above mentioned support matrices is cost effective, year round available, potential and less complex downstream processing thus unique compare to other expensive systems. The results showed that the productivity of immobilized $\alpha$-amylase was similar as free enzyme and it can be used over three cycles at industrial level.

Acknowledgement: This work was supported by the research grant of Jahangirnagar University in fiscal years 2017-2018.

\section{REFERENCES}

Antony, N., Balachandran, S. and Mohanan, P.V. 2016. Immobilization of diastase $\alpha$-amylase on nano zinc oxide. Food chemistry, 211, 624-630.

Asuri, P., Karajanagi, S.S., Sellitto, E., Kim, D.Y., Kane, R.S., and Dordick, J.S. 2006. Watersoluble carbon nanotube-enzyme conjugates as functional biocatalytic formulations, Biotechnol. Bioeng., 95(5), 804-811.

Cheetham, P.S.J. 1987. Screening for novel biocatalysts, Enzyme Microb. Technol., 9, 194-213.

Cooper, G.M. 2000. The Cell: A Molecular Approach. 2nd edition, Sinauer Associates, Inc.: Sunderland, MA, USA.

Czaja, W.K., Young, D.J., Kawecki, M. and Brown, R.M. 2007. The future prospects of microbial cellulose in biomedical applications. Biomacromolecules, 8(1), 1-12.

Gupta, R., Gigras, P., Mohapatra, H., Goswami, V.K. and Chauhan, B. 2003. Microbial $\alpha-$ amylases: a biotechnological perspective. Process biochem., 38(11), 1599-1616.

Hernandez, K. and Fernandez-Lafuente, R. 2011. Control of protein immobilization: coupling immobilization and site-directed mutagenesis to improve biocatalyst or biosensor performance, Enzyme Microb. Technol., 48(2), 107-122. 
Hernández, M.S., Rodriguez, M.R., Guerra, N.P. and Rosés, R.P. 2006. Amylase production by Aspergillus niger in submerged cultivation on two wastes from food industries, J. food eng., 73(1), 93-100.

Kandra, L. 2003. $\alpha$-amylases of medical and industrial importance, J. Mol. Struct.: THEOCHEM, 666, 487-498.

Kawaguti, H.Y., Manrich, E. and Sato, H.H. 2006. Production of isomaltulose using Erwinia sp. D12 cells: culture medium optimization and cell immobilization in alginate. Biochem. Eng. J., 29(3), 270-277.

Klemm, D., Heublein, B., Fink, H.P. et al. 2005. Cellulose: fascinating biopolymer and sustainable raw material, Angew. Chem. Int. Ed., 44:3358-3393.

Liu, Y. and Chen, J.Y. 2016. Enzyme immobilization on cellulose matrixes. J. Bioact. Compat. Polym., 31(6), 553-567.

Mehltretter, C.L. 1966. Recent progress in dialdehyde starch technology. Starch-Stärke, 18(7), 208-213.

Reshmi, R., Sanjay, G. and Sugunan, S. 2007. Immobilization of $\alpha$-amylase on zirconia: a heterogeneous biocatalyst for starch hydrolysis. Catal. Commun., 8(3), 393-399.

Robinson, P.K. 2015. Enzymes: principles and biotechnological applications, Essays Biochem., 15; 59: $1-41$.

Saifuddin, N., Raziah, A. and Junizah, A. 2013. Carbon nanotubes: a review on structure and their interaction with proteins, J. Chem., 2013, 676815,18

Sheldon, R. A. 2007. Cross-linked enzyme aggregates (CLEAs): stable and recyclable biocatalysts, Biochem. Soc. Trans., 35(6), 1583-1587.

Tangphatsornruang, S., Naconsie, M., Thammarongtham, C. and Narangajavana, J. 2005. Isolation and characterization of an $\alpha$-amylase gene in cassava (Manihot esculenta), Plant Physiol. Biochem., 43(9), 821-827.

Varavinit, S., Chaokasem, N. and Shobsngob, S. 2001. Covalent immobilization of a glucoamylase to bagasse dialdehyde cellulose, World J. Microbiol. Biotechnol., 17(7), 721-725.

Whitcomb, D.C. and Lowe, M.E. 2007. Human pancreatic digestive enzymes, Dig. Dis. Sci., 52(1), 1-17. 